THE SEAM LINE 



\section{The Seam Line}

Arab Workers and Jewish Managers

in the Israeli Textile Industry

ISRAEL DRORI

STANFORD UNIVERSITY PRESS

STANFORD, CALIFORNIA 
Stanford University Press

Stanford, California

(C) 2000 by the Board of Trustees of the

Leland Stanford Junior University

Printed in the United States of America

Library of Congress Cataloging-in-Publication Data

Drori, Israel.

The seam line: Arab workers and Jewish managers in the Israeli textile industry / Israel Drori.

p. $\mathrm{cm}$.

Includes bibliographical references and index.

ISBN 0-8047-3785-I (alk. paper) — ISBN 0-8047-3787-8 (pbk. : alk. paper)

I. Textile workers-Israel. 2. Palestinian ArabsEmployment-Israel. I. Title.

HD8039.T42 17252000

33I.7'677'0095694-de2I $\quad 99-086426$

$\infty$ This book is printed on acid-free, archival-quality paper.

Original printing 2000

Last figure below indicates year of this printing:

$\begin{array}{llllllllll}09 & 08 & 07 & 06 & 05 & 04 & 03 & 02 & \text { 01 } & 00\end{array}$

Typeset by James P. Brommer in 9.5/ I 2.5 Trump Mediaeval 